IZA DP No. 9389

Labour Market Institutions and Inflation Differentials in the EU

Gaetano D’Adamo

Riccardo Rovelli

September 2015

Forschungsinstitut zur Zukunft der Arbeit Institute for the Study of Labor 


\title{
Labour Market Institutions and Inflation Differentials in the EU
}

\author{
Gaetano D'Adamo \\ University of Valencia \\ Riccardo Rovelli \\ University of Bologna \\ and IZA
}

\section{Discussion Paper No. 9389 \\ September 2015}

\author{
IZA \\ P.O. Box 7240 \\ 53072 Bonn \\ Germany \\ Phone: +49-228-3894-0 \\ Fax: +49-228-3894-180 \\ E-mail: iza@iza.org
}

Any opinions expressed here are those of the author(s) and not those of IZA. Research published in this series may include views on policy, but the institute itself takes no institutional policy positions. The IZA research network is committed to the IZA Guiding Principles of Research Integrity.

The Institute for the Study of Labor (IZA) in Bonn is a local and virtual international research center and a place of communication between science, politics and business. IZA is an independent nonprofit organization supported by Deutsche Post Foundation. The center is associated with the University of Bonn and offers a stimulating research environment through its international network, workshops and conferences, data service, project support, research visits and doctoral program. IZA engages in (i) original and internationally competitive research in all fields of labor economics, (ii) development of policy concepts, and (iii) dissemination of research results and concepts to the interested public.

IZA Discussion Papers often represent preliminary work and are circulated to encourage discussion. Citation of such a paper should account for its provisional character. A revised version may be available directly from the author. 
IZA Discussion Paper No. 9389

September 2015

\section{ABSTRACT}

\section{Labour Market Institutions and Inflation Differentials in the EU}

Adopting a simple Phillips curve framework, we show that different labour market institutions across EU countries are associated with significant differences in the response of inflation to unemployment and exchange rate shocks. More wage coordination and higher union density flatten the Phillips curve and increase the inflation response to the real exchange rate, i.e. the exchange rate pass-through. In addition, using a new approach to the classification of goods and services as "traded" or "non-traded", we show that both these institutional effects are significantly stronger for the more exposed (traded) sector.

JEL Classification: $\quad \mathrm{E} 31, \mathrm{~J} 50, \mathrm{~J} 60$

Keywords: labour market institutions, inflation determinants, sectoral inflation differentials, EU 27

Corresponding author:

Riccardo Rovelli

Department of Economics

University of Bologna

Strada Maggiore 45

40125 Bologna

Italy

E-mail: riccardo.rovelli@unibo.it 
IZA Discussion Paper No. 9389

September 2015

\section{NON-TECHNICAL SUMMARY}

Does the rate of change of the prices of goods and services depend on their degree of tradability? In addition, do these differences in sectoral inflation vary across countries? And is it possible that they are related to the rigidity of labor market institutions?

Since prices of traded goods and services are a prime determinant of a country's competitiveness, we believe that it is interesting also from a policy perspective to understand what determines sectoral inflation and how institutions affect the response of inflation to macroeconomic shocks.

In our paper we focus on whether, and to what extent, some characteristics of the labor market (in particular, union density and the degree of coordination in wage bargaining) may modify the response of inflation to macroeconomic shocks. Our approach allows these characteristics to have different effects on inflation in the traded versus the non-traded sectors.

Our results (based on a study of 26 EU countries from 1994 to 2012) show that different labour market institutions (LMI) are associated with important heterogeneity in inflation adjustment across countries. First, we find that the inflation rate is generally higher for the non-traded sectors, relative to the traded ones. On average, the within-country differential was $2.8 \%$ in $1994-98,2.0 \%$ in 1999-2007, and then shrunk to 0.3 in 2008-2012 (a period of almost deflation, throughout Europe).

Second, we find that this differential varies across countries, as a function of their LMI: in general, stronger wage coordination and higher union density increase inflation everywhere, but especially in the traded sector.

Third, we also find that stronger or more rigid institutions tend to reduce the adjustment to unemployment and increase the exchange rate pass through. Again, this effect is significantly larger for the traded sector.

These findings suggest that different LMI may be at the root of some unfavourable patterns of price competitiveness, especially in the euro area. Another implication is that differences in the common monetary policy may have asymmetric transmission effects across the euro area, depending on each country's LMI. Thus, institutionally heterogeneous labour markets may be associated with significant departures from an optimal monetary area. 


\section{Introduction}

Modern versions of the Phillips curve describe the key relation between unemployment and inflation in most macro models. Within this broad framework, a wide array of theoretical models and empirical works show how inflation may be further affected by macroeconomic shocks such as to the oil price, international prices and the exchange rate. ${ }^{1}$

Empirical estimates of the inflationary impact of different types of shocks vary a lot both across countries and across different sectors in the same country. These differences are influenced, among other things, by the degree of openness of the economy and by the tradability of specific goods and services: in a small open economy we expect prices of traded goods (more precisely, the prices of goods and services produced in sectors more exposed to foreign price competition) to be internationally determined, while the prices of non-traded goods or services (which are produced in the more sheltered sectors) may also be affected by domestic factors. Indeed, it is a well-established stylized fact that the inflation rate measured for the non-traded sector is higher than that measured for the traded sector. A reason for this, according to the Scandinavian model of inflation (Aukrust, 1970) is that labour productivity grows faster in the traded sector; as wages increase there, due to free labour mobility across sectors, firms in the sector producing nontradable goods or services will have to raise wages as well, and compensate wage increases with higher prices. $^{2}$

\footnotetext{
${ }^{1}$ See Svensson (1997 and 2000), Gali and Monacelli (2005), Bowdler and Nunziata (2007), Biroli, Mourre and Turrini (2010).

${ }^{2}$ In the original formulation of the Scandinavian model, wages are set exogenously. However, as Paunio and Halttunen (1976) observe, "there is an implicit 'theory' about the determination of wages: productivity changes in the exposed industries and world market prices determine them if
} 
In addition, while relative inflation is generally higher in the non-traded sector, the two are not perfectly correlated, which may reflect the fact that prices in these two sectors respond with different speed and intensity to the same macro shocks. Figure 1 shows the evolution of both measures of inflation in the EU-27 between 1994 and 2012. The average correlation between the two series is 0.85 , but inflation is generally higher in the non-traded sector, with few exceptions especially in more recent years. ${ }^{3}$

\section{[Insert Figure 1 here]}

Since prices in the traded sector are a prime determinant of a country's competitiveness, we think that it is interesting also from a policy perspective to understand the determinants of sectoral inflation and how institutions affect the response of inflation to macroeconomic shocks. In these respect, many policy analyses have stressed the importance of increasing labour market flexibility to restore the competitiveness of those EMU countries that have accumulated large external imbalances. As these countries do not have the possibility of adjusting the nominal exchange rate vis-à vis each other, adjustments must occur via internal devaluation, that is through wage and price adjustments.

In this paper we focus on whether, and to what extent, some characteristics of the labour market (in particular, union density and the degree of coordination in wage bargaining) may modify the response of inflation to macroeconomic shocks. Our approach allows these characteristics to have different effects on inflation in the

the exchange rate is fixed". This same mechanism may be used to rationalize the BalassaSamuelson effect in catching up economies (see Section 2 below).

${ }^{3}$ Since 1997, the average annual inflation rate for tradables in the EU-27 has been 1.9\%, while that for non-tradables has reached $2.7 \%$, but the standard deviation of the former is more than double than the latter. The higher cyclical volatility of inflation for tradables was especially evident in the recession year 2009. 
traded versus the non-traded sectors. In general, we follow the approach set by Bowdler and Nunziata (2007) to estimate a simple reduced-form equation for inflation (a Phillips curve), adding interactions between macroeconomic variables and labour market institutional indicators as explanatory variables, and we apply this approach separately for the price indexes of traded and non-traded goods.

Our results show that there are important differences in inflation adjustment across countries, due to labour market institutions (LMI). We find that stronger or more rigid institutions tend to reduce the adjustment to unemployment and increase the exchange rate pass through. This effect is significantly larger for the traded sector.

The paper is organized as follows. Section 2 reviews the relevant literature. Section 3 introduces the dataset and the empirical model. In Section 4 we describe the methodology for classifying traded and non-traded goods and services. We evaluate the empirical results in Section 5. Section 6 concludes.

\section{Literature review}

There is a wide amount of theoretical and empirical macroeconomic literature on inflation determination. Since Phillips (1958), and then following the critiques and reformulations of Phelps (1967) and Friedman (1968), research on the issue has generally modelled inflation as being determined by the economic cycle (i.e. the deviation of unemployment from the long-run level or the output gap); inflation expectations, generally modelled as a weighted average of past inflation and other inflation indicators; the exchange rate and/or imported inflation, for a small open 
economy; and some variable representing the government's fiscal policy (for example, indirect taxes and/or the public deficit to GDP ratio) ${ }^{4}$.

One issue that has been investigated in specific reference to the Euro Area is the reason for the persistence of inflation differentials within the same currency area. A large part of these differentials can be explained as a consequence of price level convergence between countries with different levels of income per capita (as suggested by the Penn effect), and also by movements in the effective exchange rate and the business cycle. ${ }^{5}$

Other researchers have explored the potential role of labour and product market institutions in affecting price formation and possibly also on inflation. It is natural to expect that LMI may have an impact on price formation by affecting the marginal cost of labour and by changing transaction costs relate to the hiring and firing of workers $^{6}$; however, this in general does not help to explain persistent changes in the inflation rate. Similarly, product market regulations may strengthen the market power of firms and, as a result, allow for higher mark-ups and thus for higher prices, but again this does not generally have direct implications on the evolution of inflation over time.

In this respect, simple specifications of the inflation process do not generally find that LMI contribute to its explanation. However, a different brand of literature

\footnotetext{
${ }^{4}$ See, among others, Svensson (1997 and 2000) and Gali and Monacelli (2005).

${ }^{5}$ See Stavrev (2007), Angeloni and Ehrmann (2007). de Haan (2010) surveys this literature.

${ }^{6}$ For instance, Nunziata (2005) shows that stricter employment protection, higher union density and higher unemployment benefits are associated with a higher aggregate wage, while coordination in wage bargaining has a significant negative effect on wages. Also Layard, Nickell and Jackman (1991) and Nickell, Nunziata and Ochel (2005) show that, by allowing wages to be set at a higher level than the market-clearing one, stricter LMI reduce labour demand and therefore are associated with higher unemployment.
} 
has taken a more subtle approach, which builds on the earlier approach of Blanchard and Wolfers (2000). These authors showed that, while neither macro shocks nor institutions per se can explain the persistence of high unemployment through time, it is really the interactions of shocks and institutions that lead to a larger and more persistent effect of shocks on unemployment. In a similar spirit, Andres, Ortega and Vallés (2008), in a two-country model which is calibrated to mimic large euro area countries, show that inflation reacts faster to macroeconomic shocks in countries where markets are more competitive. Along this line, Bowdler and Nunziata (2007) and Jaumotte and Morsy (2012) use a traditional backward-looking Phillips curve framework to estimate the effect of labour and product market institutions on the reaction of inflation to different types of shocks. In both cases, their evidence, respectively based on a sample of 20 OECD countries for 1961-1995 and on 10 euro area countries for 1983-2007, supports the hypothesis that more rigid labour market structures weaken the responsiveness of inflation to macro unemployment shocks and also to changes in the import prices or the exchange rate.

In this paper, we focus on the interactions between LMI and macro shocks to explain the dynamic behaviour of inflation (with the modifications that will be discussed below). We leave aside the role that might be played by product market regulations (PMR) for two reasons. First, PMR are predominantly related to the services sector. Second, introducing PMR measures together with measures of LMI would create 
serious problems of multicollinearity in our model, ${ }^{7}$ and this would make it difficult to disentangle the effects of the two types of regulations. ${ }^{8}$

Our approach to modelling the inflationary impact of the interactions between shocks and institutions differs from that pursued so far in the literature in two main respects. First, as already anticipated, we maintain throughout the analysis a distinction between sectors producing traded and non-traded goods and services. This distinction is necessary to assess the relevance of Balassa-Samuelson (B-S) effects to explain the different competitive performance of EU countries. The B-S hypothesis states that those countries that are in the process of catching up will experience an appreciation of the real exchange rate; this is due to the fact that productivity grows faster in the tradable goods sector than in the non-tradable sector, thus pushing up wages (but not unit costs) in the former. Since inter-sectoral labour mobility ensures wage equalization across domestic macro sectors, wages in the non-tradable sector increase in parallel: this pushes up prices in the non-traded sector, which ultimately causes an appreciation of the real exchange rate (with, in principle, no loss of competitiveness). In the literature on convergence, different authors have used alternative approaches to assess the importance of the B-S effect but, broadly speaking, the main result is that it can account only for a minor part of the excess inflation observed in Central and Eastern European Countries (CEEC) since the early 1990's(see Egert et.al., 2003 and Egert, 2007). These results suggest

\footnotetext{
${ }^{7}$ Results of the models estimated in Section 4 including PMR measures are available from the authors upon request. The correlation between PMR and LMI measures interacted with the macroeconomic variables is always above 0.80 .

8 This problem is compounded by the fact that the OECD index of economy-wide PMR is available only for 3 years, making an econometric analysis unfeasible for the group of countries we are interested in, while the annual index of PMR available from the OECD is mostly representative of services as it refers to airlines, telecoms, electricity, gas, post, rail, and road freight, and is not available until 2007 for Slovenia and Estonia, and until 2002 for Slovakia.
} 
that other factors may indeed be at play $^{9}$, and here we wish to explore the possible role of LMI in this respect.

Second, we differ from most papers adopting a Phillips curve approach, as we do not include lagged measures of inflation (our dependent variable) nor measures of inflation expectations. The main motivation is that, for EU countries (including those that became members in 2004 or 2007) both actual and expected inflation were well anchored to the medium-run target of two percent (similar targets were also adopted by non-EMU members, such as Denmark, Sweden and UK, and also by those that adopted the euro later on, such as the Baltic states). This anchoring of inflation expectations precludes the use of those proxies that are often included in models applied to periods of high and volatile inflation. In addition, these proxies are not available in our case: first, because in a relatively short time-horizon (1994-2012, with annual data) it is not feasible to estimate a panel including the lagged dependent variable; second, because independent measures of inflation (such as survey data) are not available for the generality of the countries in our dataset; third, because in any case we would need these measures computed at our level of disaggregation (traded vs. non traded). In any case, as we discuss below, we test adequately for the exclusion of these variables from our specifications, and find no signs of mis-specification.

\footnotetext{
${ }^{9}$ One effect that has been suggested in particular is related to Engel's law, which postulates that, during the catching up process, consumers move to higher-quality goods, thus indirectly pushing up the observed CPI (Égert and Podpiera 2008 and Egert 2010).
} 


\section{Data and econometric methodology}

We use annual data from 1994 to 2012 for the EU-27 countries. The shortness of the sample is due to the availability of price series for traded and non-traded goods for some of the countries, Germany in particular; moreover, we excluded Malta from the sample due to lack of data (see Section 4). We consider two alternative samples: EU27 minus Malta and EU-21, i.e. the EU member States that are also in the OECD. The more restricted sample enables us to take into account some institutional variables that are available only for OECD countries. This sample excludes also Bulgaria Cyprus, Latvia, Lithuania, Romania.

A common practice in the empirical literature ${ }^{10}$ has been to approximately identify the traded sector with the production of goods and the non-traded sector with that of services. In general, this is a reasonable empirical assumption, especially when looking at the more distant past ${ }^{11}$. However, trade in services is now increasing at a fast pace, and such a sharp distinction is gradually losing plausibility. In fact, it is easy to find examples of non-traded goods, and symmetrically of highly traded services. Also, the distinction itself between goods and services is becoming increasingly imprecise. ${ }^{12}$ For this reason, in the next section we will identify traded and non-traded sectors by calculating their degree of tradability, or openness.

\footnotetext{
10 See Mihaljek and Klau (2004) for a review.

${ }^{11}$ As an example, note that the share of services in total EU -27 Gross Value Added (excluding the construction industry) was $77.6 \%$ in 2011, while that in total EU- 27 exports was only 24,4\% (Source: Eurostat).

${ }^{12}$ See Christensen (2013), who concludes that "The increasing complexity of production, inertia in changes to statistical systems and the increasing integration of manufacturing products and services are some of the primary and interrelated explanations for this lack of precision". In addition, as Nordas and Kim (2013) observe, the competitiveness of services in also a key ingredient for manufacturing competitiveness.
} 
Data on LMI come from the OECD and the ICTWSS database. ${ }^{13}$ The inflation equation that we estimate, separately for the traded and non-traded sectors, is the following:

$$
\inf _{i j, t}=\alpha_{i j}+\delta_{j t}+\beta_{j} X_{i, t}+\gamma_{j} Z_{i, t} * X_{i, t}+\varepsilon_{i j, t}
$$

where $j=N, T$ refers to non-traded and traded sectors respectively and $i=1, \ldots, 26$ are the countries. The $\alpha$ represent country fixed effects and $\delta$ represent year dummies. $X$ is a vector of "macroeconomic variables", and $Z$ is a vector of "institutional variables".

The macroeconomic variables included are the deviation of unemployment from its long-run trend (ucycle) $)^{14}$ and the real effective exchange rate (REER). To avoid endogeneity problems, and because the exchange rate may affect inflation with some lag, REER is lagged one year. This is also consistent with the fact that changes in international prices may affect domestic prices with some delay. ${ }^{15}$

The institutional or policy variables that we include are Wage Coordination $(W C O O R)$, which measures the degree of coordination in wage bargaining, and Union Density (UD), which measures the share of the employed who are members of a union, as a proxy of unions' bargaining power. ${ }^{16}$

13 Detailed definitions of all the variables and sources are reported in the Data Appendix.

14 The unemployment trend has been removed with an HP filter. As a robustness check, we have also performed the estimations using a model-based natural unemployment rate.

15 In a preliminary analysis, the following macroeconomic variables were also included: growth rate of labour productivity (measured as gross value added per person), percentage changes in the indirect tax wedge, and imported inflation. However, none come out to be significant. The finding that productivity growth does not impact (negatively) on inflation suggests that all productivity gains are transferred to the factors of production, via higher profits or wages. Also note that a better measure of productivity growth would have been the rate of change of gross value added per hour worked; however using this measure would have seriously reduced our sample in both the time and space dimensions.

16 The degree of Employment Protection (EPL) and the Minimum Wage Ratio, as measured by the OECD were also included in a preliminary analysis but never came out to be significant, confirming 
To interpret the regression results, note that the $\gamma$ coefficients in eq. (1) measure the marginal effect of LMI on the adjustment of inflation to, respectively, the unemployment rate and the real exchange rate. These marginal effects will therefore vary across countries and through time following the different characteristics of LMI and their evolution in time. Thus, the marginal effect on inflation in country $i$, sector $j$, time $t$ of a macroeconomic variable, say ucycle, will be given by the sum of two components:

$$
\beta_{j} X_{i, t}+\gamma_{j} Z_{i, t} X_{i, t}
$$

where $X_{i, t}=$ ucycle $(i, t)$. Notice that, for any macro shock, the only idiosyncratic (country-specific) element in a country's response to that shock is the specific value attributed to the LMI included in vector $Z_{i t}$.

To estimate equation (1), we use a fixed effects OLS regression. The validity of OLS depends on whether the variables included in the model are I(0) or cointegrated. As ucycle is constructed as the deviation of unemployment from the HP trend, it is stationary by definition. All tests confirm that also REER is stationary, while in the case of traded and non-traded goods inflation nonstationarity is rejected by most of the tests carried out. Since panel unit root tests on the residuals of the regressions performed always reject the nonstationarity of residuals, we can safely proceed with OLS. ${ }^{17}$ Note that these tests also validate our exclusion of the lagged dependent variable.

the finding (for EPL) of Bowdler and Nunziata (2007). Centralization in wage bargaining (CENT in the ICTWSS database) was also excluded, due to serious problems of multicollinearity with WCOOR. 17 We performed Pesaran's (2007) CADF test, that also accounts for cross-section dependence (CSD), which is pervasive in our sample, as shown by a previous CSD test (Pesaran, 2004). Results of CSD and panel unit root tests are available on request. 
An additional issue concerns the assumption that the slope coefficients $\beta_{j}$ are homogeneous across countries. This assumption is quite rigid, but also necessary to ensure the validity of our adopted specification. However, in the context of our model, we relax this rigidity, as we allow different slopes to arise out of the interactions between the macro and institutional variables, as shown in equation (2). However, as the different degree of trade openness may be an additional cause of heterogeneity, we also performed the regressions correcting the macro regressors using the degree of openness (as in Bowdler and Nunziata, 2007). The results were unchanged.

\section{The classification of "traded" and "non-traded" sectors}

As discussed in Section 3, the definition of the "traded" versus "non-traded" sectors must be handled with care. In fact, although this distinction is generally sharp in the literature, it is much less extreme in reality. Most researchers identify the open sector with industry and the sheltered sector with services or "all the rest". This is the case, among others, of Egert (2002, 2003a, 2003b) and Golinelli and Orsi (2002). Halpern and Wyplosz (2001) compare price behavior for services versus non-food manufacturing. Also Coricelli and Jazbec (2004) exclude agriculture from the traded sector, while Nenovsky and Dimitrova (2002) include constructions in the traded sector.

In this paper we choose a different, evidence-based approach. In order to separate between traded and non-traded sectors, we ordered all sectors according to their degree of tradability, defined as the ratio between the value of international trade for sector $i$ and gross added value of that sector: 


$$
t r_{i}=\frac{e x_{i}+i m_{i}}{g v a_{i}}
$$

where $t r$ is the degree of tradability, ex is the aggregate of all EU countries' exports (both intra- and extra-EU), im is the aggregate of all EU imports and gva is the gross value added in sector i. We calculate this measure for each sector as the EU-27 average over the sample period (1994-2012). This allows us to order all sectors from the most open until the least open ${ }^{18}$.

How did we define the sectors? For value added, we used Eurostat NACE-R2 classification with 64 sectors. However, to have a more detailed decomposition of exports and imports, for goods we used trade data from the SITC classification, and for services from Balance of Payment (BoP) data ${ }^{19}$. As the NACE, SITC and BoP data are based on different sector classifications, we merged the data, as shown in Table 1, in twenty-five groups. Of the 64 NACE-R2 sectors, ten do not have import-export data, so we consider them "by definition" non-traded. They are listed at the bottom of Table 1 and indicated with "NT" (Non-Traded) ${ }^{20}$. Table 2 shows the 25 sectors ordered according to their tradability in the EU-27 in the average of 1994-2012 21. There is a clear distinction between goods and services: the output of all top 9 sectors is goods, and that of all the 16 bottom sectors is services. On the other hand, however, some services clearly have a degree of tradability comparable to that of goods.

\footnotetext{
${ }^{18}$ All data come from Eurostat. We used GVA instead of total output by sector to obtain a larger sample size (due to data availability).

${ }^{19}$ As far as services are concerned, balance of payment data are only available for the EU-28 from 2004 onwards, while they are available for the EU-15 also from 1985. Therefore, we report the results for the EU-28 here. The calculation using also pre-2004 data on EU-15 gave qualitatively similar results.

${ }^{20}$ Detailed information on the composition of NACE-R2 sectors and the relationship with previous classifications is available at: http://epp.eurostat.ec.europa.eu/cache/ITY_OFFPUB/KS-RA-07015/EN/KS-RA-07-015-EN.PDF.

${ }^{21}$ For services, we take the average of 2004-2012. See the text below for comments.
} 


\section{[ Insert Tables 1 and 2 here ]}

A reasonable criterion for separating between traded and non-traded sectors is to choose a cutoff point at $t r_{i}=1$. All sectors with a value of the index higher than one are taken to be "traded". Sectors with $1<t r_{i} \leq 0.25$ are included in a "grey area" and excluded from the empirical analysis. Sectors with $t r_{i}<0.25$ are classified as "non-traded". We believe this approach yields a satisfactory classification. All goodsproducing sectors (except for constructions) are in the traded group, together with some services. Also notice that while the index for goods is computed over the whole sample (1994-2012), it includes only the period 2004-2012 for services. As trade in goods within the EU increased significantly after 2004, if anything the index is more "conservative" for goods than for services. To verify the validity of our choice, we also calculated the same indexes for each country. Overall, the ranking indicated in Table 2 and in particular the distinction between traded and non-traded sectors appears to be valid for all countries, with only few exceptions like, for example, finance and insurance in the UK and Luxembourg. We will go back to this point in section 5.2 . 


\section{Facts and findings}

\subsection{Regression results}

As Figure 1 shows, inflation in the non-traded sector has generally been higher than in the traded sector. To look at the data in more detail, Table 3a reports the means of some key variables for the three periods 1994-98 (before the euro); 1999-2007 (early euro years), and 2008-2012 (Great Recession). Table 3b shows the same data for each country.

\section{[Insert Tables 3a, 3b here]}

Looking at Table 3a, we observe that: (i) inflation for both the traded and non-traded sector has been declining through the three periods, and the difference between the two sectors has narrowed; (ii) inflation in both sectors has become less persistent, as measured by the correlation with the previous year's inflation; (iii) the structure of labour markets has become more flexible: wage setting is less coordinated and union density has declined (a pattern which confirms a trend observed in previous periods for many countries, also outside the EU; see Riley, 1997).

Table $3 \mathrm{~b}$ reports the means of our key variables by country, which summarize the diversity in macroeconomic conditions within the EU-26 sample. In this table, we also report GDP per capita at the beginning of the sample period, 1995. We shall use this indicator in the next section to divide the sample countries into groups. In the table, we also observe that UD has its lowest level in France, which apparently contradicts this country's high union coverage ${ }^{22}$. In this case, we believe that UD is not a good proxy for union power in France and, to avoid that this waters down our

\footnotetext{
22 The coverage rate of wage bargaining agreements in France, adjusted for those sectors where bargaining is not possible, was $90 \%$ in 2008 according to ICTWSS data.
} 
results, we shall perform the regressions that include this independent variable both with and without France (see Section 5.2).

Our empirical strategy is first to estimate a simple Phillips curve (the "base inflation equation"), which only includes the macro explanatory variables (vector $X$ in equation 1). Then, we estimate the complete models with interactions.

\section{[Insert Table 4 here]}

Table 4 reports the results of the OLS estimation of the base inflation equation for the EU-26, including country fixed effects and year dummies. All macro variables are significant and signed according to our expectations. Columns (1) and (2) show the results for the traded and non-traded sectors respectively. An increase of the unemployment rate by $1 \%$ above trend causes inflation to fall by $0.25 \%$ in the traded sector and by $0.60 \%$ in the non-traded sector, and a $1 \%$ real depreciation (a fall in REER) increases inflation by $0.13 \%$ and $0.19 \%$ respectively. To test whether these differences are significant, column (3) reports the results of using relative inflation, $\inf l_{T}-\inf l_{N}$, as a dependent variable. This confirms that the impact of unemployment and real exchange rate changes on inflation in the non-traded sectors is significantly larger (in absolute value) than in the traded sectors. The plausible explanation for this difference is that non-traded sectors are more likely to be characterized by mark-up pricing, while traded sectors are characterized by pricing to market and subject to international competition. Hence, non-traded sector prices are more responsive to domestic macroeconomic shocks.

In the next stage, we introduce in the base regressions the interactions between the macro and institutional variables (vector $Z$ in equation 1 ). Results are reported in Table 5. The introduction of LMI may create a problem of multicollinearity with the 
country fixed effects, as there is often very little within country variation. For this reason, we change our regression model to replace country fixed effects with country groups fixed effects, as in Rovelli and Zaiceva (2013). In fact, one may argue that differences in inflation levels across the EU countries are due to some factors, like in particular convergence à la Balassa-Samuelson, that are common to more countries, and plausibly related (as suggested by the literature on the Penn effect) to each country's per capita GDP level. Accordingly, we formed country groups based on the ranking of the EU-26 countries according to their GDP per capita at the beginning of the sample. We thus replace the vector $\alpha_{i j}$ of country fixed effects with vector $\mu_{i j}=\left[\right.$ bgro $_{i j}$, baltic $_{i j}, \operatorname{ceec}_{i j}$, periph $\left.h_{i j}\right]$, where bgro is a dummy equal to 1 for Bulgaria and Romania and zero otherwise; baltic is equal to 1 for Estonia, Latvia and Lithuania; ceec is equal to 1 for the Czech Republic, Slovakia, Slovenia, Hungary and Poland; and periph is the dummy for Ireland, Portugal, Cyprus, Spain and Greece. The residual group includes the remaining 11 countries (all among the "old" EU members) in our sample.

\section{[Insert Table 5 here]}

Table 5 reports the results of the estimation of equation (1) including, alternatively, WCOORD or $U D$. We include these two institutional variables separately because they are unsurprisingly collinear, as the impact of unions' bargaining power is likely to be well proxied by measures of the degree of wage coordination ${ }^{23}$.

In general, this analysis confirms all the previous results from the baseline model on the roles of unemployment and the real exchange rate. Moreover, we now find that, other things equal, more wage coordination and higher union density imply higher

\footnotetext{
${ }^{23}$ See Nunziata (2005), Nickell and Layard (1999) and Boeri, Brugiavini and Calmfors (2001).
} 
inflation, both in the traded and non-traded sectors. These institutional arrangements also reduce the impact of unemployment on inflation, i.e. they flatten the Phillips curve, while they increase the exchange rate pass-through. We interpret the former result as suggesting that more centralized wage coordination and higher union membership act as a buffer between wages and cyclical shocks, which then results in a flatter Phillips curve. Regarding the response to the real exchange rate, it is consistent with the plausible joint hypothesis that (a) more centralized wage bargaining and/or higher union membership allow unions to negotiate higher wages following a real depreciation in order to avoid losses in workers' purchasing power, and (b) that this in turn translates into higher inflation. We notice that the effects of $W C O O R$ and $U D$ are always qualitatively identical. As in the baseline model, we also performed the regression on relative inflation $\left(i n f l_{T}-i n f l_{N}\right)$, in order to investigate whether such differences are significant. As we had previously found in the baseline model, also in this case we confirm that both ucycle and REER have a significantly larger absolute impact in the non-traded sector (see columns (3) and (6) of Table 5). Also, notice that, while WCOOR has a larger impact on inflation in the traded sector, it does not have a differential impact on the slope of the Phillips curve, which is almost equally "flattened" by greater WCOOR for both sectors. Instead, greater $W C O O R$ increases the extent of exchange rate pass-through significantly more in the traded sector than in the non-traded one.

Another insight offered by Table 5 corroborates the choice of focusing on group fixed effects. This is the fact that the magnitude of the coefficient of the group dummies follow the group rankings in terms of GDP per capita: it is higher for Bulgaria and Romania, followed by the Baltics, the CEECs and finally the Eurozone Periphery. For the last group, the coefficient is not always significant, indicating that 
inflation behaves in a similar way to that of the core EU members. All this is fully consistent with the hypothesis of price convergence à la Balassa-Samuelson.

While the regressions for the traded sector inflation and relative inflation do not point to any evidence of serial correlation (neither in the base equation nor when we include LMI), we see evidence of first order autocorrelation in all the equations for non-traded sector inflation. This motivates us to test the robustness of our results in this respect (see next section).

A different way to look at our results is to compute how they explain the different patterns of inflation adjustment in the different countries. For this purpose, in the four panels of Figure 2, we graphically show the estimated point values of inflation response to unemployment and real exchange rate shocks, for all the EU-26 countries. The coefficients are computed as in equation (2), where the $\beta$ and the $\gamma$ coefficients in the inflation equations for the traded and non-traded sectors are taken from the estimates in columns (1) and (2) of Table 5, respectively. ${ }^{24}$ In each panel of Figure 2 we show, for each country, the sum of the estimated adjustment coefficient of sectoral inflation to a macro shock (which is the same for all countries) plus the idiosyncratic adjustment term, estimated from the interaction term between each country's LMI and the macro shock variable.

\section{[Insert Figure 2 here]}

Panels (a) and (b) of Figure 2 show how inflation in the traded and non-traded sectors, respectively, reacts to unemployment shocks. The response of non-traded inflation to unemployment shocks is generally larger than in the traded sector (on

\footnotetext{
24 These two models have been selected on the basis of the standard error of the regression.
} 
average, -0.20 for traded and -0.52 for non-traded). However, there are large differences in each country's responsiveness, which are related to their different levels of coordination in wage bargaining. Where coordination is high, responsiveness to unemployment shocks is lower (or even negative, as it happens for the traded sector in Austria, Denmark, Belgium and Finland). Where it is low, the Phillips curve is steeper, as is the case for both sectors in the Baltics, Poland and the UK.

Panels (c) and (d), instead, show an opposite different idiosyncratic response of sectoral inflation to exchange rate shocks: in both sectors, the pass-through is much larger in countries where WCOOR is higher, and smaller in countries where it is low (as in the Baltics, Poland, and the UK).

\subsection{Robustness checks}

We check the robustness of our estimates in several ways: (i) including only the pre2009 years, in order to remove the effects of the recession and the euro crisis; (ii) using different measures of cyclical unemployment; (iii) modifying the classification of traded and non-traded sectors; (iv) changing the estimation technique and (v) the model specification. Results of robustness checks (i) - (iii) are reported in Table 6; (iv) and (v) are reported in Table 7.

\section{[Insert Table 6 here]}

For (i), the results of removing the years from 2009 onwards are reported in columns (1)-(6) of Table 6. Despite the shorter sample, previous results are confirmed: the inflation response to unemployment and real exchange rate shocks is stronger (in absolute value) in the non-traded sectors than in the traded ones, whereas LMI, and UD in particular, have a stronger impact on traded inflation. 
Coefficients are in general larger than in Table 5, but the qualitative results are all confirmed.

For (ii), recall from section 3 that we estimated the unemployment cycle variable using a Hodrick-Prescott (HP) filter on observed unemployment rates. The use of the HP filter has been criticized on several grounds, in particular as it may amplify cycles and it is sensitive to the length of the sample over which the trend is estimated. For this reason, we alternatively used a simple "model-based" measure of the natural rate, taking the fitted values from a regression of the unemployment rate on union density and wage coordination. The model-based cyclical unemployment rate is thus defined as:

$$
\text { ucycle }_{i t}^{M}=\text { unemp }_{i t}-\widehat{\text { unemp }} p_{i t}
$$

where the second term on the right hand side is the predicted unemployment rate from the regression. As it can be seen from the estimates in columns (5)-(8), all previous results are confirmed.

For (iii), we might doubt whether the classification of traded vs. non traded sectors described in section 4 remains valid for all countries. Some types of services may have a very different degree of openness across the EU, for preference or regulatory differences. This is especially evident for financial and insurance services. In these sectors, the openness of Luxembourg and the UK sets them apart from the other countries. As we observed in Section 4, Finance and Insurance fall in our "grey area" and were not included in our regression analysis. However, since this sector also represents a sizable share of GDP in both Luxembourg and the UK, we repeated the 
empirical analysis alternatively excluding one of these countries from the sample. As shown in columns (9) - (12), results are unchanged 25 .

For (iv) and (v), we noted in section 5.1 that the estimated residuals from the inflation equations for the non-traded sector are autocorrelated. To address this issue, we re-estimated the model assuming $\mathrm{AR}(1)$ disturbances as in Baltagi and Wu (1999) (see Table 7, columns (1)-(2)). Alternatively, observed autocorrelation may signal the omission of relevant information from the model. In particular, it may be the case that previous year inflation from the other sector affects the current inflation rate in each sector. To account for this, we expand the specification in equation (1) to include cross-sector lagged inflation (see columns (3)-(6)).

\section{[insert Table 7 here]}

In all cases, changes in the estimation method or the specification do not alter our previous results. The one exception is that, for the non-traded sector, now WCOOR affects inflation significantly only through its interaction with ucycle (see columns (1) and (4)). More generally, the inclusion of cross-lagged dependent variables provides evidence of significant inflation spillovers across the two sectors. On the other hand, we must remark that the inclusion of these additional variables does not eliminate the auto correlation of the estimated residuals for the non-traded sector. However, the results from GLS estimation (columns (1) and (2)) strongly support the conclusion that our main results on the role of LMI in the inflation equations are robust also in this respect.

\footnotetext{
25 Reported equations in columns (9) - (12) exclude Luxembourg. Results for the UK are similar. Results are also robust to the exclusion of France, which, as discussed in section 5.1, is characterized by very low union density in spite of high union coverage. Results of all the additional robustness checks are available from the authors upon request.
} 


\section{Conclusions}

In this paper we have analysed how LMI may affect the adjustment of inflation to macroeconomic events, allowing for the adjustment to be different for the prices of traded and non-traded goods or services. Using a sample of 20 OECD countries for 1961-1995, Bowdler and Nunziata (2007) had shown that, in general, more rigid LMI tend to curb the adjustment of inflation to changes in macroeconomic variables. In our case, we chose to analyse inflation in the traded and non-traded sectors separately, since the two sectors face different competitive pressures, and because price developments in each sector may have very different implications for the external competitiveness of an economy.

Focusing on a sample of 26 EU countries for 1994-2012, we measured the degree of output tradability for different sectors. We confirm that goods are generally more tradable than services, albeit with some important exceptions (in particular, for professional services, accommodation and transport services).

In the econometric part of the paper, we model inflation in a simple augmented Phillips curve framework. We find that the patterns of inflation adjustment are different between tradables and non-tradables. The reaction of non-tradables inflation to unemployment and real exchange rate shocks is significantly more pronounced. This confirms the basic hypothesis that, for relatively small open economies, domestic factors are less relevant in determining the evolution of the prices of traded goods.

These results are confirmed when we introduce LMI in the analysis, and we explicitly model their interactions with macro shocks. First, we observe that, other 
things equal, stronger coordination in wage bargaining and higher union density are associated with higher inflation in both sectors, but this effect is stronger for tradables. In respect of the responsiveness to macro shock, we find that stronger coordination in wage bargaining and higher union density have two main effects: they curb the effect of unemployment shocks on inflation, i.e. they flatten the Phillips curve, and generate a stronger reaction of inflation to real exchange rate shocks.

These results suggest that differences in these LMI contribute to generate significant cross-country differences in inflation dynamics: as wage coordination and/or union strength increase, wages and henceforth prices become less sensitive to unemployment shocks. On the other hand, unions that are more powerful may be able to obtain wages increases to avoid losses in purchasing power after a real depreciation, thus causing a higher (in absolute value) exchange rate pass-through to inflation.

These observations may be important from a normative viewpoint. In a monetary union, such as the euro area, differences in LMI imply that monetary policy may have asymmetric transmission effects across countries. Thus, institutionally heterogeneous labour markets may be associated with significant departures from an optimal monetary area.

\section{References}

Angeloni, I., and Ehrmann, M. (2007) "Euro area inflation differentials". The B.E. Journal of Macroeconomics 7 (1), Article 24.

Andrés, J., Ortega, E., and Vallés, J. (2008) "Competition and inflation differentials in EMU”. Journal of Economic Dynamics and Control 32 (3), pp. 848-874. 
Aukrust, O. (1970) "PRIM 1: A model of the price and income distribution mechanism of an open economy". The Review of Income and Wealth 16 (1), pp. 5178.

Baltagi, B. (1995) Econometric analysis of Panel Data, New York: Wiley.

Baltagi, B. H., and Wu, P. X. (1999). "Unequally spaced panel data regressions with AR(1) disturbances". Econometric Theory 15, pp. 814-823.

Biroli, P., Mourre, G., and Turrini, A. (2010) "Adjustment in the euro area and regulation of product and labour markets: an empirical assessment". CEPR Discussion Paper No. DP 8010.

Blanchard, O., and Wolfers, J. (2000) "The role of shocks and institutions in the rise of european unemployment: the aggregate evidence". The Economic Journal 110, pp. C1-C33.

Bowdler, C. and Nunziata, L. (2007) "Inflation adjustment and labour market structures: evidence from a multi-country study". Scandinavian Journal of Economics 109(3), pp. 619-642.

Christensen, J.L. (2013) "The ability of current statistical classifications to separate services and manufacturing". Structural Change and Economic Dynamics 26, pp. 47-60.

de Haan (2010) "Inflation Differentials in the Euro Area: A Survey. In: J. de Haan and H. Berger (eds.), The European Central Bank at Ten, Berlin Heidelberg: SpringerVerlag, pp.11-32.

Drukker, D. M. 2003. Testing for serial correlation in linear panel-data models. Stata Journal (3)2: 168-177.

Egert, B. (2007) “Real convergence, price level convergence and inflation in Europe”. Bruegel Working Paper $\mathrm{N}^{\circ}$ 2007/02.

Egert, B. (2010) “Catching up and inflation in Europe: Balassa-Samuelson, Engel's Law and other culprits". OECD Economics Department Working Paper $\mathrm{N}^{\circ} 792$, OECD Publishing.

Egert, B., Drine, I., Lommatzsch, K., and Rault, C. (2003) "The Balassa-Samuelson effect in Central and Eastern Europe: myth or reality?". Journal of Comparative Economics 31 (3), pp. 552-72.

Egert, B., and Podpiera, J. (2008) "Structural inflation and real exchange rate appreciation in Visegrad-4 countries: Balassa-Samuelson or something else?" CEPR Policy Insight No. 20, London: CEPR.

Friedman, M. (1968) "The role of monetary policy." American Economic Review 58 (1), pp. 1-17.

Gali, J. and Monacelli, T. (2005) "Monetary policy and exchange rate volatility in a small open economy", Review of Economic Studies 72, pp. 707 - 734. 
Jaumotte, F. and H. Morsy (2012) "Determinants of inflation in the Euro Area: the role of labour and product market institutions", IMF Working Paper WP/12/37.

Layard, R., Nickell, J. S. and R. Jackman (1991). Unemployment: Macroeconomic Performance and the Labour Market, Oxford: Oxford University Press.

Mihaljek, D. and M. Klau. 2004. “The Balassa-Samuelson effect in Central Europe: a disaggregated analysis". Comparative Economic Studies, 46(1), pp. 63-94.

Nickell, S., Nunziata, L., and Ochel, W. (2005) "Unemployment in the OECD since the 1960s. What do we know?" The Economic Journal, 115, pp. 1-27.

Norda, H.K., and Kim, Y. (2013) "The role of services for competitiveness in manufacturing". OECD Trade Policy Papers No. 148, OECD Publishing.

Nunziata, L. (2005) "Institutions and wage determination: a multi-country approach". Oxford Bulletin of Economics and Statistics 67: 435-466.

Paunio, J.J., and Halttunen, H. (1976) "The 'Nordic' approach to inflation: interpretation and comments". In: M. Parkin and G.Zis (eds.) Inflation in the world economy. Manchester: Manchester U.P., pp. 259-272.

Phelps, E.S. (1967) "Phillips curves, expectations of inflation and optimal employment over time." Economica 34 (3), pp. 254-281.

Phillips, A. W. (1958). "The relationship between unemployment and the rate of change of money wages in the United Kingdom 1861-1957". Economica 25 (100), pp. 283-299.

Riley, N.M. (1997) “Determinants of union membership: a review”. Labour 11 (2), pp. 265-301.

Stavrev, E. (2007) "Growth and inflation dispersions in EMU: reasons, the role of adjustment channels, and policy implications". IMF Working Papers 07/167, International Monetary Fund.

Svensson, L.E.O. (1997) "Inflation forecast targeting: implementing and monitoring inflation targets”. European Economic Review 41, pp. 111 - 1146.

Svensson, L.E.O. (2000) "Open-economy inflation targeting”, Journal of International Economics 50, pp. 155-183.

Visser, J. (2011) "Database on institutional characteristics of trade unions, wage setting, state intervention and social pacts, 1960-2010 (ICTWSS)". Downloaded from: http://www.uva-aias.net/208.

Wooldridge, J. M. 2002. Econometric Analysis of Cross Section and Panel Data. Cambridge, MA: MIT Press. 


\section{Data Appendix}

\section{Variable Definition and Source}

infl $_{T} \quad$ Annual \% change in the HCPI for traded sector. Source: Eurostat and authors' calculations.

$\operatorname{infl}_{N} \quad$ Annual \% change in the HCPI for non-traded sector. Source: Eurostat and authors' calculations.

ucycle Unemployment rate, de-trended with HP filter. Source: Eurostat.

REER Real Effective Exchange Rate. Source: International Financial Statistics, IMF.

UD Union Density; Source: OECD Statistics

WCOOR Wage Coordination. Source: ICTWSS Database, http://www.uvaaias.net/208.

exp Exports, intra- and extra-EU. Source: Eurostat.

imp Imports, intra- and extra-EU. Source: Eurostat. 
Figure 1. Traded and non-traded goods inflation 1994-2012

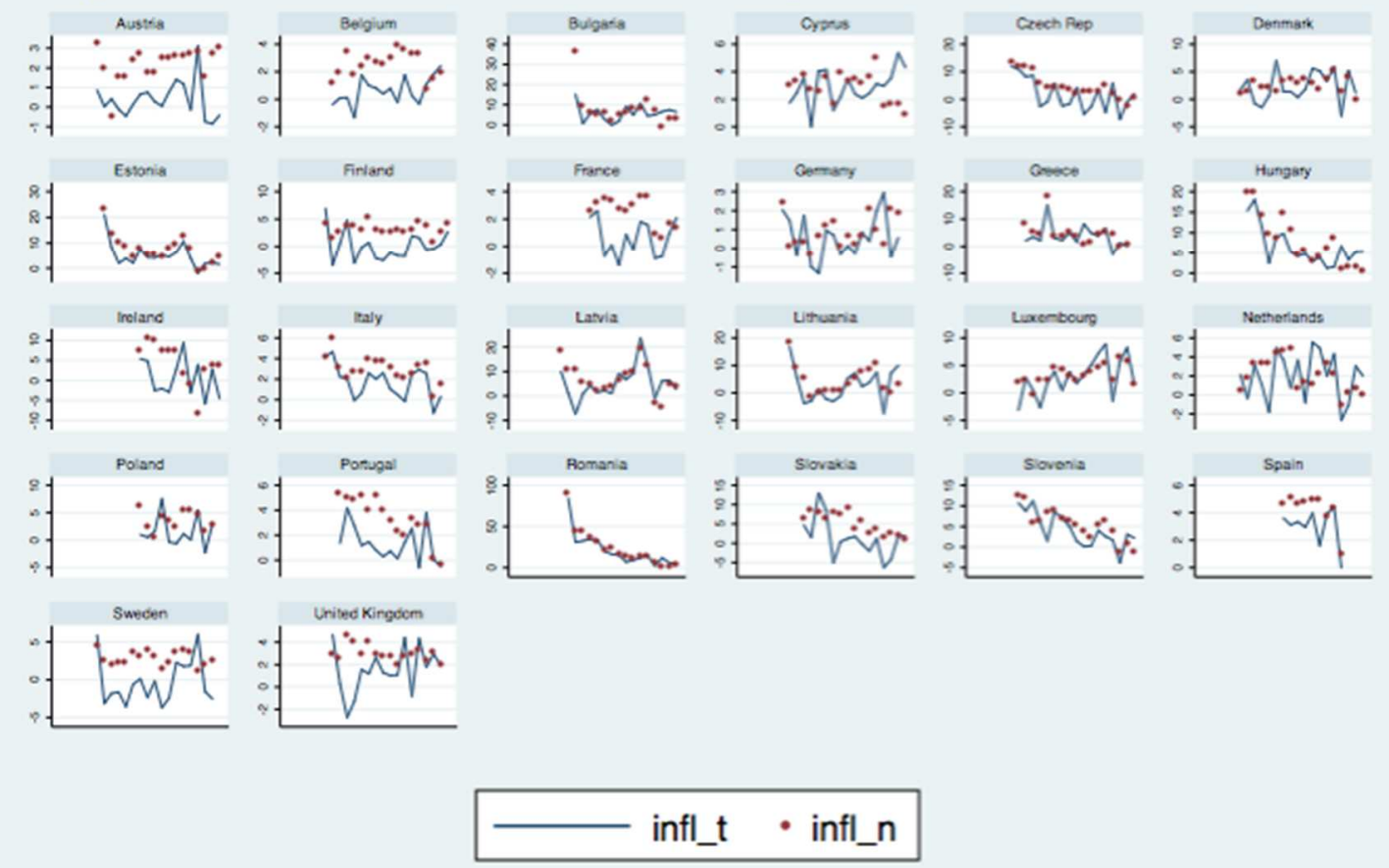

Source: Eurostat. 
Figure 2. Inflation response to macro shocks by country
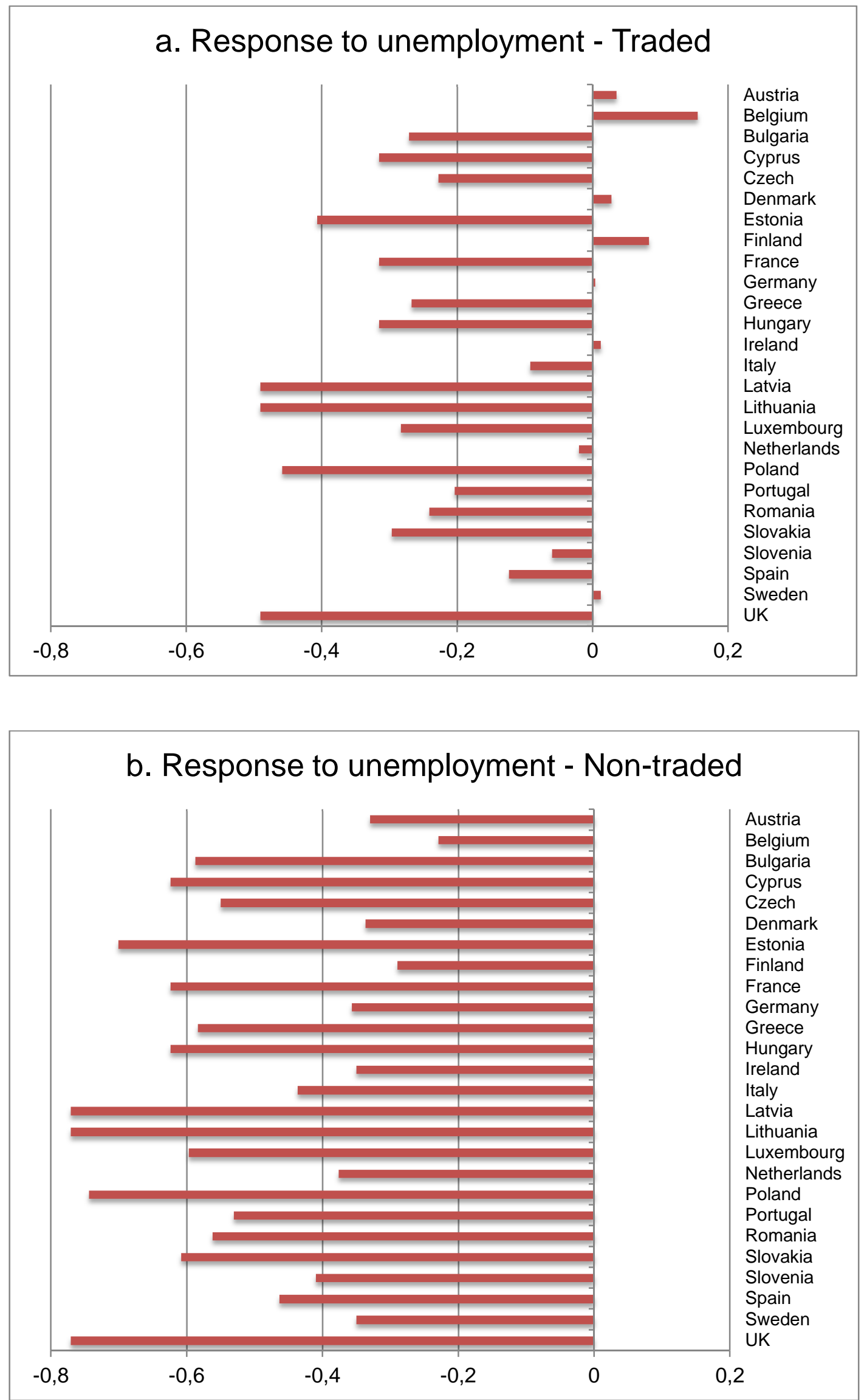

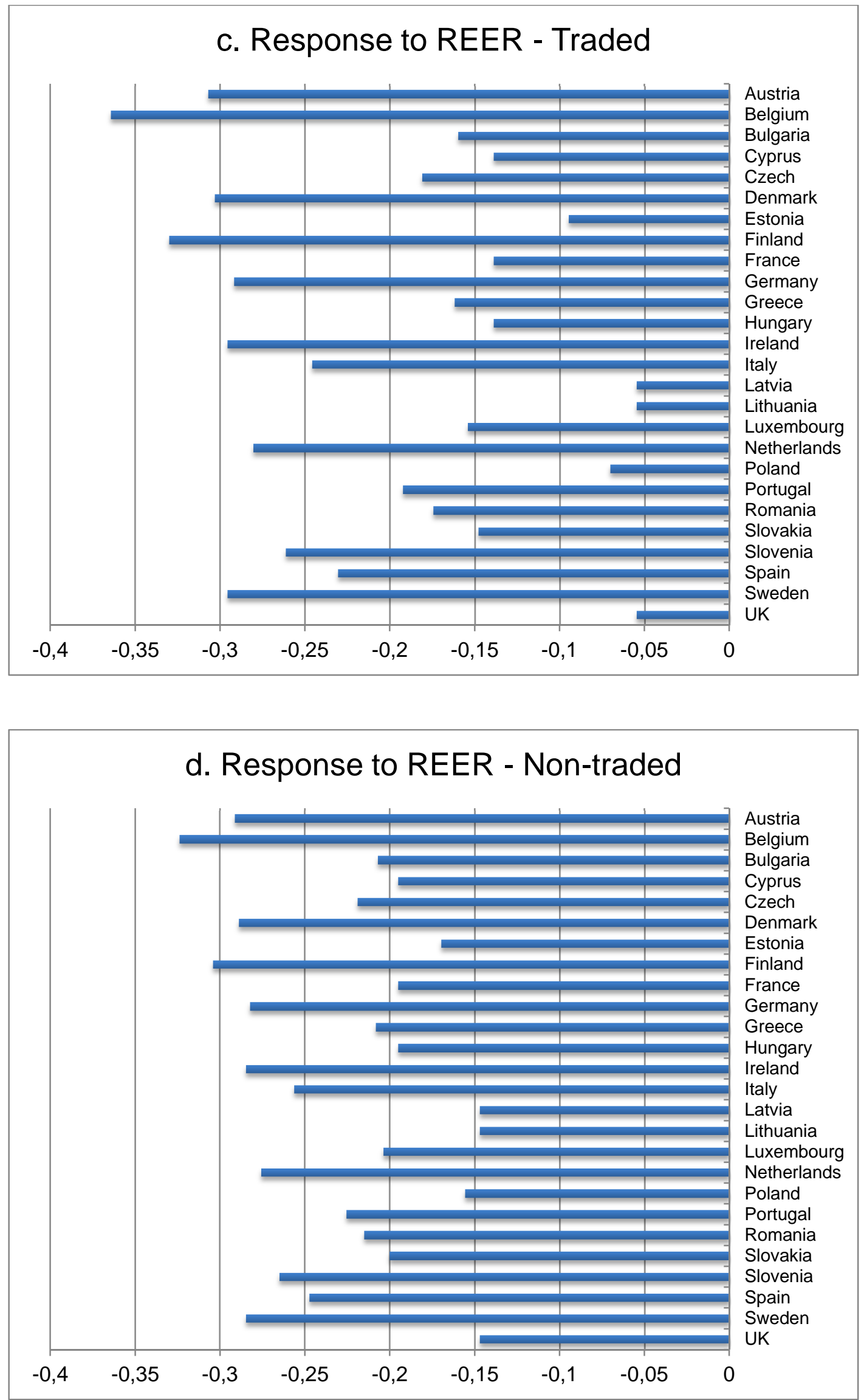
Table 1. Sectors in the Nace-R2, SITC and Balance of Payments classifications

\begin{tabular}{|c|c|c|c|}
\hline No. & $\begin{array}{l}\text { NACE- } \\
\text { R2 }\end{array}$ & GVA NACE-R2 Sector & $\begin{array}{l}\text { Trade data Sector with } \\
\text { classification number }\end{array}$ \\
\hline \multirow{4}{*}{1} & A01 & $\begin{array}{l}\text { Crop and animal production, hunting and related } \\
\text { service activities }\end{array}$ & \multirow{4}{*}{$\begin{array}{l}\text { 0. Food and live animals } \\
\text { 1. Beverages and tobacco } \\
\text { 2. Crude materials, inedible, } \\
\text { except fuels } \\
\text { 4. Animal and vegetable oils, } \\
\text { fats and waxes }\end{array}$} \\
\hline & A02 & Forestry and logging & \\
\hline & A03 & Fishing and aquaculture & \\
\hline & $\begin{array}{l}\text { C10 } \\
-\mathrm{C} 12\end{array}$ & $\begin{array}{l}\text { Manufacture of food products; beverages and } \\
\text { tobacco products }\end{array}$ & \\
\hline \multirow[b]{2}{*}{2} & $\mathrm{~B}$ & Mining and quarrying & \multirow{2}{*}{$\begin{array}{l}\text { 3. Mineral Fuels, Lubricants } \\
\text { and related materials (coke, } \\
\text { petroleum, electric current, } \\
\text { gas...) }\end{array}$} \\
\hline & $\mathrm{D}$ & Electricity, gas, steam and air conditioning supply & \\
\hline \multirow{8}{*}{3} & C16 & $\begin{array}{l}\text { Manufacture of wood and of products of wood } \\
\text { and cork, except furniture; manufacture of } \\
\text { articles of straw and plaiting materials }\end{array}$ & \multirow{8}{*}{$\begin{array}{l}\text { 6.0 Complete industrial plant } \\
\text { appropriate to section } 6 \\
\text { 6.1 Leather, leather manuf. } \\
\text { 6.2 Rubber manufactures } \\
\text { 6.3 Cork and wood manufact. } \\
\text { 6.4 Paper,... } \\
\text { 6.5 Textile yarns, fabrics,... } \\
\text { 6.6 Nonmetallic mineral } \\
\text { manufactures n.e.s. } \\
\text { 6.7 Iron and Steel } \\
\text { 6.7 Non-ferrous metals } \\
\text { 6.9 Manufactures of metals, } \\
\text { n.e.s. }\end{array}$} \\
\hline & $\mathrm{C} 17$ & Manufacture of paper and paper products & \\
\hline & C18 & Printing and reproduction of recorded media & \\
\hline & C19 & $\begin{array}{l}\text { Manufacture of coke and refined petroleum } \\
\text { products }\end{array}$ & \\
\hline & $\mathrm{C} 22$ & Manufacture of rubber and plastic products & \\
\hline & $\mathrm{C} 23$ & $\begin{array}{l}\text { Manufacture of other non-metallic mineral } \\
\text { products }\end{array}$ & \\
\hline & $\mathrm{C} 24$ & Manufacture of basic metals & \\
\hline & $\mathrm{C} 25$ & $\begin{array}{l}\text { Manufacture of fabricated metal products, except } \\
\text { machinery and equipment }\end{array}$ & \\
\hline 4 & $\begin{array}{l}\text { C13 } \\
-\mathrm{C} 15\end{array}$ & $\begin{array}{l}\text { Manufacture of textiles, wearing apparel, leather } \\
\text { and related products }\end{array}$ & $\begin{array}{l}\text { 8.3 Travel goods, handbags } \\
\text { 8.4 Articles of apparel and } \\
\text { clothing accessories } \\
\text { 8.5 Footwear }\end{array}$ \\
\hline \multirow[b]{2}{*}{5} & $\mathrm{C} 20$ & Manufacture of chemicals and chemical products & \multirow{2}{*}{$\begin{array}{l}\text { 5. Chemical and related } \\
\text { products }\end{array}$} \\
\hline & $\mathrm{C} 21$ & $\begin{array}{l}\text { Manufacture of basic pharmaceutical products } \\
\text { and pharmaceutical preparations }\end{array}$ & \\
\hline \multirow[b]{4}{*}{6} & $\mathrm{C} 26$ & $\begin{array}{l}\text { Manufacture of computer, electronic and optical } \\
\text { products }\end{array}$ & \multirow{4}{*}{$\begin{array}{l}\text { 7.1 Power-generating } \\
\text { machinery } \\
\text { 7.2 Machinery specialized for } \\
\text { specific industries } \\
\text { 7.3 Metalworking machinery } \\
\text { 7.4 General ind. machinery } \\
\text { 7.5 Office machines } \\
\text { 7.6 Telecommunication } \\
\text { equipment } \\
\text { 7.7 Electrical equipment } \\
\text { 8.7 Professional, scientific and } \\
\text { controlling instruments } \\
\text { 8.8 Photographic apparatus, } \\
\text { equipment and supplies and } \\
\text { optical goods }\end{array}$} \\
\hline & $\mathrm{C} 27$ & Manufacture of electrical equipment & \\
\hline & $\mathrm{C} 28$ & Manufacture of machinery and equipment n.e.s. & \\
\hline & $\mathrm{C} 33$ & $\begin{array}{l}\text { Repair and installation of machinery and } \\
\text { equipment }\end{array}$ & \\
\hline
\end{tabular}




\begin{tabular}{|c|c|c|c|}
\hline 7 & C29 & $\begin{array}{l}\text { Manufacture of motor vehicles, trailers and semi- } \\
\text { trailers }\end{array}$ & 7.8 Road vehicles \\
\hline 8 & C30 & Manufacture of other transport equipment & 7.9 Other transport equipment \\
\hline 9 & $\begin{array}{l}\text { C31 } \\
-\mathrm{C} 32\end{array}$ & Manufacture of furniture; other manufacturing & $\begin{array}{l}\text { 8.1 Prefabricated } \\
8.2 \text { Furniture and parts thereof; } \\
\text { bedding; mattresses... } \\
8.9 \text { Misc. manuf. articles }\end{array}$ \\
\hline \multirow{2}{*}{10} & $\mathrm{~F}$ & Construction & \multirow{2}{*}{ 249. Construction Services } \\
\hline & $\mathrm{L}$ & Real estate activities & \\
\hline \multirow{3}{*}{11} & G45 & $\begin{array}{l}\text { Wholesale and retail trade and repair of motor } \\
\text { vehicles and motorcycles }\end{array}$ & \multirow{3}{*}{$\begin{array}{l}\text { 269. Other business services - } \\
\text { Merchanting and other trade- } \\
\text { related services }\end{array}$} \\
\hline & G46 & $\begin{array}{l}\text { Wholesale trade, except of motor vehicles and } \\
\text { motorcycles }\end{array}$ & \\
\hline & G47 & $\begin{array}{l}\text { Retail trade, except of motor vehicles and } \\
\text { motorcycles }\end{array}$ & \\
\hline \multirow{4}{*}{12} & $\mathrm{H} 49$ & Land transport and transport via pipelines & \multirow{4}{*}{ 205. Transportation } \\
\hline & $\mathrm{H} 50$ & Water transport & \\
\hline & H51 & Air transport & \\
\hline & H52 & $\begin{array}{l}\text { Warehousing and support activities for } \\
\text { transportation }\end{array}$ & \\
\hline 13 & H53 & Postal and courier activities & $\begin{array}{l}\text { 246. Postal and courier } \\
\text { services }\end{array}$ \\
\hline 14 & $\begin{array}{l}J 59 \\
-J 60\end{array}$ & $\begin{array}{l}\text { Motion picture, video, television programme } \\
\text { production; programming and broadcasting } \\
\text { activities }\end{array}$ & $\begin{array}{l}\text { 288. Audio-visual and related } \\
\text { services }\end{array}$ \\
\hline 15 & J61 & Telecommunications & 247. Telecommunication serv. \\
\hline 16 & $\begin{array}{l}J 62 \\
-J 63\end{array}$ & $\begin{array}{l}\text { Computer programming, consultancy, and } \\
\text { information service activities }\end{array}$ & $\begin{array}{l}\text { 262. Computer and information } \\
\text { services }\end{array}$ \\
\hline 17 & K64 & $\begin{array}{l}\text { Financial service activities, except insurance and } \\
\text { pension funding }\end{array}$ & 260. Financial Services \\
\hline \multirow{2}{*}{18} & K65 & $\begin{array}{l}\text { Insurance, reinsurance and pension funding, } \\
\text { except compulsory social security }\end{array}$ & \multirow{2}{*}{ 253. Insurance services } \\
\hline & K66 & $\begin{array}{l}\text { Activities auxiliary to financial services and } \\
\text { insurance activities }\end{array}$ & \\
\hline \multirow{5}{*}{19} & \begin{tabular}{|l|l|} 
M69 \\
-M70
\end{tabular} & $\begin{array}{l}\text { Legal and accounting activities; activities of head } \\
\text { offices; management consultancy activities }\end{array}$ & \multirow{5}{*}{$\begin{array}{l}\text { 273. Other business services - } \\
\text { Miscellaneous business, } \\
\text { professional and technical } \\
\text { services (Includes: legal, } \\
\text { accounting, marketing, R\&D }\end{array}$} \\
\hline & M71 & $\begin{array}{l}\text { Architectural and engineering activities; technical } \\
\text { testing and analysis }\end{array}$ & \\
\hline & M72 & Scientific research and development & \\
\hline & M73 & Advertising and market research & \\
\hline & $\begin{array}{l}\text { M74- } \\
\text { M75 }\end{array}$ & $\begin{array}{l}\text { Other professional, scientific and technical } \\
\text { activities; veterinary activities }\end{array}$ & \\
\hline 20 & N77 & Rental and leasing activities & $\begin{array}{l}\text { 272. Operational leasing } \\
\text { services }\end{array}$ \\
\hline 21 & 0 & $\begin{array}{l}\text { Public administration and defence; compulsory } \\
\text { social security }\end{array}$ & 291. Government services, n.i.e. \\
\hline \multirow{3}{*}{22} & $\mathrm{P}$ & Education & \multirow{3}{*}{$\begin{array}{l}\text { 895. Education services } \\
\text { 896. Health services }\end{array}$} \\
\hline & Q86 & Human health activities & \\
\hline & $\begin{array}{l}\text { Q87 } \\
-Q 88\end{array}$ & $\begin{array}{l}\text { Residential care activities and social work } \\
\text { activities without accommodation }\end{array}$ & \\
\hline
\end{tabular}




\begin{tabular}{|c|c|c|c|}
\hline \multirow[t]{2}{*}{23} & $\begin{array}{l}\text { R90 } \\
-\mathrm{R} 92\end{array}$ & $\begin{array}{l}\text { Creative, arts and entertainment activities; } \\
\text { libraries, archives, museums and other cultural } \\
\text { activities; gambling and betting activities }\end{array}$ & \multirow{2}{*}{$\begin{array}{l}\text { 897. Other personal, cultural } \\
\text { and recreational services - } \\
\text { other }\end{array}$} \\
\hline & R93 & $\begin{array}{l}\text { Sports activities and amusement and recreation } \\
\text { activities }\end{array}$ & \\
\hline \multirow[b]{2}{*}{24} & I & Accommodation and food service activities & \multirow[b]{2}{*}{ 236. Travel } \\
\hline & N79 & $\begin{array}{l}\text { Travel agency, tour operator reservation service } \\
\text { and related activities }\end{array}$ & \\
\hline \multirow{10}{*}{ NT } & $\begin{array}{l}\mathrm{N} 80 \\
-\mathrm{N} 82\end{array}$ & $\begin{array}{l}\text { Security and investigation, service and landscape, } \\
\text { office administrative and support activities }\end{array}$ & \multirow{10}{*}{ N.A. } \\
\hline & E36 & Water collection, treatment and supply & \\
\hline & $\begin{array}{l}\text { E37 } \\
\text {-E39 }\end{array}$ & $\begin{array}{l}\text { Sewerage, waste management, remediation } \\
\text { activities }\end{array}$ & \\
\hline & N78 & Employment activities & \\
\hline & J58 & Publishing activities & \\
\hline & S94 & Activities of membership organisations & \\
\hline & S95 & $\begin{array}{l}\text { Repair of computers and personal and household } \\
\text { goods }\end{array}$ & \\
\hline & S96 & Other personal service activities & \\
\hline & $\mathrm{T}$ & $\begin{array}{l}\text { Activities of households as employers; } \\
\text { undifferentiated goods- and services-producing } \\
\text { activities of households for own use }\end{array}$ & \\
\hline & $\mathrm{U}$ & $\begin{array}{l}\text { Activities of extraterritorial organisations and } \\
\text { bodies }\end{array}$ & \\
\hline
\end{tabular}

Legenda: n.i.e= not included elsewhere; n.e.s.= not elsewhere specified; N.A.=Not applicable. 
Table 2. Sectors ordered by degree of tradability $\left(t r_{i}\right)$

\begin{tabular}{|c|c|c|}
\hline No. & GVA NACE-R2 Sector & $\mathbf{T r}_{\mathbf{i}}$ \\
\hline 8 & Manufacture of other transport equipment & 5.5875 \\
\hline 5 & $\begin{array}{l}\text { Manufacture of chemicals and chemical products; Manufacture of } \\
\text { basic pharmaceutical products and pharmaceutical preparations }\end{array}$ & 5.4507 \\
\hline 7 & Manufacture of motor vehicles, trailers and semi-trailers & 5.3447 \\
\hline 9 & Manufacture of furniture; other manufacturing & 4.8347 \\
\hline 6 & $\begin{array}{l}\text { Manufacture of computer, electronic and optical products; } \\
\text { Manufacture of electrical equipment; Repair and installation of } \\
\text { machinery and equipment; Manufacture of machinery and } \\
\text { equipment n.e.c. }\end{array}$ & 4.5252 \\
\hline 4 & $\begin{array}{l}\text { Manufacture of textiles, wearing apparel, leather and related } \\
\text { products }\end{array}$ & 3.6416 \\
\hline 2 & $\begin{array}{l}\text { Mining and quarrying } \\
\text { Electricity, gas, steam and air conditioning supply }\end{array}$ & 2.169 \\
\hline 3 & $\begin{array}{l}\text { Manufacture of wood and of products of wood and cork, except } \\
\text { furniture; manufacture of articles of straw and plaiting materials } \\
\text { Manufacture of paper and paper products } \\
\text { Printing and reproduction of recorded media } \\
\text { Manufacture of coke and refined petroleum products } \\
\text { Manufacture of rubber and plastic products } \\
\text { Manufacture of other non-metallic mineral products } \\
\text { Manufacture of basic metals } \\
\text { Manufacture of fabricated metal products, except machinery and } \\
\text { equipment }\end{array}$ & 2.053 \\
\hline 1 & $\begin{array}{l}\text { Crop and animal production, hunting and related service activities } \\
\text { Forestry and logging } \\
\text { Fishing and aquaculture } \\
\text { Manufacture of food products; beverages and tobacco products }\end{array}$ & 1.8979 \\
\hline 12 & $\begin{array}{l}\text { Land transport and transport via pipelines } \\
\text { Water transport } \\
\text { Air transport } \\
\text { Warehousing and support activities for transportation }\end{array}$ & 1.4940 \\
\hline 24 & $\begin{array}{l}\text { Accommodation and food service activities } \\
\text { Travel agency, tour operator reservation service and related } \\
\text { activities }\end{array}$ & 1.4310 \\
\hline 19 & $\begin{array}{l}\text { Legal and accounting activities; activities of head offices; } \\
\text { management consultancy activities } \\
\text { Architectural and engineering activities; technical testing and } \\
\text { analysis } \\
\text { Scientific research and development } \\
\text { Advertising and market research } \\
\text { Other professional, scientific and technical activities; veterinary } \\
\text { activities }\end{array}$ & 1.0358 \\
\hline
\end{tabular}




\begin{tabular}{|c|c|c|}
\hline 18 & $\begin{array}{l}\text { Insurance, reinsurance and pension funding, except compulsory } \\
\text { social security } \\
\text { Activities auxiliary to financial services and insurance activities }\end{array}$ & 0.5028 \\
\hline 16 & $\begin{array}{l}\text { Computer programming, consultancy, and information service } \\
\text { activities }\end{array}$ & 0.5007 \\
\hline 17 & Financial service activities, except insurance and pension funding & 0.3264 \\
\hline 13 & Postal and courier activities & 0.3128 \\
\hline 15 & Telecommunications & 0.2851 \\
\hline 14 & $\begin{array}{l}\text { Motion picture, video, television programme production; } \\
\text { programming and broadcasting activities }\end{array}$ & 0.2689 \\
\hline 23 & $\begin{array}{l}\text { Creative, arts and entertainment activities; libraries, archives, } \\
\text { museums and other cultural activities; gambling and betting } \\
\text { activities } \\
\text { Sports activities and amusement and recreation activities }\end{array}$ & 0.2329 \\
\hline 20 & Rental and leasing activities & 0.2114 \\
\hline 11 & $\begin{array}{l}\text { Wholesale and retail trade and repair of motor vehicles and } \\
\text { motorcycles } \\
\text { Wholesale trade, except of motor vehicles and motorcycles } \\
\text { Retail trade, except of motor vehicles and motorcycles }\end{array}$ & 0.0881 \\
\hline 21 & Public administration and defence; compulsory social security & 0.0449 \\
\hline 10 & $\begin{array}{l}\text { Construction } \\
\text { Real estate activities }\end{array}$ & 0.0250 \\
\hline 22 & $\begin{array}{l}\text { Education } \\
\text { Human health activities } \\
\text { Residential care activities and social work activities without } \\
\text { accommodation }\end{array}$ & 0.0043 \\
\hline NT & $\begin{array}{l}\text { Water collection, treatment and supply } \\
\text { Sewerage, waste management, remediation activities } \\
\text { Security and investigation, service and landscape, office } \\
\text { administrative and support activities } \\
\text { Employment activities } \\
\text { Publishing activities } \\
\text { Activities of membership organisations } \\
\text { Repair of computers and personal and household goods } \\
\text { Other personal service activities } \\
\text { Activities of households as employers; undifferentiated goods- and } \\
\text { services-producing activities of households for own use } \\
\text { Activities of extraterritorial organisations and bodies }\end{array}$ & 0 \\
\hline
\end{tabular}


Table 3a. Summary statistics by period

\begin{tabular}{cccc} 
Period & $1994-1998$ & $1999-2007$ & $2008-2012$ \\
\hline $\operatorname{mean}\left(i n f_{T}\right)$ & 5.39 & 2.89 & 2.08 \\
$\operatorname{mean}\left(i n f_{N}\right)$ & 8.17 & 4.89 & 2.42 \\
$\sigma\left(i n f_{T}\right)$ & 11.73 & 5.35 & 3.85 \\
$\sigma\left(i n f_{N}\right)$ & 12.99 & 5.14 & 3.06 \\
$\rho\left(i n f_{T, t}, i n f_{N, t}\right)$ & 0.94 & 0.83 & 0.36 \\
$U D$ & 41.66 & 34.13 & 29.07 \\
$W C O O R$ & 2.79 & 2.72 & 2.56 \\
\hline
\end{tabular}

Note: Average values across 26 countries for each sub-period. See Data Appendix for definition of variables. $\sigma()=$. standard deviation; $\rho()=$. correlation.

Table $\mathbf{3 b}$. Summary statistics by country

\begin{tabular}{ccccccc} 
& inf & inf & unemp & $\begin{array}{c}\text { GDP p.c. } \\
(€, 1995)\end{array}$ & UD & WCOOR \\
\hline Austria & 1.23 & 2.24 & 6.60 & 23,000 & 34.5 & 4 \\
Belgium & 1.78 & 2.11 & 9.66 & 21,500 & 52.7 & 4.38 \\
Bulgaria & 5.80 & 6.71 & 11.92 & 1,200 & 26.6 & 2.12 \\
Cyprus & 2.32 & 2.93 & 3.69 & 10,800 & 63.4 & 2 \\
Czech Rep. & 4.05 & 7.37 & 7.06 & 4,300 & 26.0 & 2 \\
Denmark & 1.50 & 2.91 & 6.96 & 26,600 & 73.1 & 3.31 \\
Estonia & 6.55 & 10.29 & 8.84 & 2,000 & 14.1 & 1 \\
Finland & 1.02 & 2.52 & 11.16 & 19,600 & 74.0 & 3.63 \\
France & 1.43 & 2.07 & 9.08 & 20,200 & 8.0 & 2 \\
Germany & 1.37 & 1.58 & 9.44 & 23,600 & 23.2 & 4 \\
Greece & 3.70 & 5.02 & 10.14 & 8,500 & 26.5 & 4 \\
Hungary & 4.92 & 5.92 & 8.62 & 3,400 & 24.4 & 2 \\
Ireland & 1.44 & 3.76 & 9.75 & 14,400 & 40.8 & 4.63 \\
Italy & 2.29 & 2.87 & 9.44 & 15,200 & 34.8 & 4 \\
Latvia & 4.89 & 6.23 & 9.24 & 1,500 & 18.0 & 1 \\
Lithuania & 3.11 & 5.56 & 7.69 & 1,400 & 15.1 & 1 \\
Luxembourg & 2.25 & 2.50 & 3.40 & 38,600 & 41.8 & 2.13 \\
Netherlands & 1.57 & 2.71 & 5.14 & 20,700 & 22.3 & 4 \\
Poland & 4.78 & 6.61 & 13.77 & 2,800 & 22.3 & 1 \\
Portugal & 1.97 & 3.69 & 6.64 & 9,000 & 22.0 & 2.88 \\
Romania & 9.94 & 10.2 & 7.70 & 1,300 & 37.0 & 2.50 \\
Slovakia & 4.72 & 7.34 & 13.42 & 2,800 & 31.1 & 2.88 \\
Slovenia & 5.08 & 8.48 & 11.27 & 8,100 & 40.2 & 4.06 \\
Spain & 2.50 & 3.60 & 16.09 & 11,600 & 15.8 & 3.5 \\
Sweden & 1.47 & 2.17 & 6.20 & 22,000 & 76.5 & 3 \\
U.K. & 0.55 & 3.58 & 6.65 & 15,600 & 29.4 & 1 \\
\hline See Data A & & & &
\end{tabular}

See Data Appendix for definition of variables. 
Table 4. Base inflation equations

\begin{tabular}{lccc}
\hline & $(1)$ & $(2)$ & $(3)$ \\
VARIABLES & Traded & Non-Traded & Relative \\
\hline u_cycle & $-0.247^{* *}$ & $-0.595^{* * *}$ & $-0.356^{* * *}$ \\
& $(0.121)$ & $(0.091)$ & $(0.121)$ \\
reert-1 & $-0.128^{* * *}$ & $-0.192^{* * *}$ & $-0.063^{* *}$ \\
& $(0.026)$ & $(0.025)$ & $(0.019)$ \\
Constant & $12.989^{* * *}$ & $21.843^{* * *}$ & $8.833^{* * *}$ \\
& $(2.882)$ & $(3.272)$ & $(3.238)$ \\
Country FE & YES & YES & YES \\
Year FE & YES & YES & YES \\
\hline Observations & 397 & 397 & 397 \\
R-squared & 0.772 & 0.844 & 0.284 \\
\hline & -8.421 & -3.321 & -8.703 \\
Unit root test (p-value) & $(0.000)$ & $(0.000)$ & $(0.000)$ \\
\hline Test for no serial correlation (p- & 1.501 & 20.747 & 0.272 \\
value) & $(0.232)$ & $(0.001)$ & $(0.607)$ \\
\hline Robust standard errors in parentheses. ${ }^{* * *}$ p $<0.01,{ }^{* *} \mathrm{p}<0.05, * \mathrm{p}<0.1$. Unit root test is Pesaran's $(2007)$ \\
CADF with no trend and 1 lag. Test for residual autocorrelation is as in Woolridge (2002) and Drukker \\
(2003). & & &
\end{tabular}


Table 5. LMI and sectoral inflation

\begin{tabular}{|c|c|c|c|c|c|c|}
\hline VARIABLES & $\begin{array}{c}(1) \\
\text { Traded }\end{array}$ & $\begin{array}{c}(2) \\
\text { Non-Traded }\end{array}$ & $\begin{array}{c}\text { (3) } \\
\text { Relative }\end{array}$ & $\begin{array}{c}(4) \\
\text { Traded }\end{array}$ & $\begin{array}{c}(5) \\
\text { Non-Traded }\end{array}$ & $\begin{array}{c}\text { (6) } \\
\text { Relative }\end{array}$ \\
\hline \multirow[t]{2}{*}{ u_cycle } & $-0.315^{* *}$ & $-0.624^{* * *}$ & $-0.313^{* * *}$ & $-0.497^{* *}$ & $-0.775^{* * *}$ & $-0.278^{*}$ \\
\hline & $(0.128)$ & $(0.095)$ & $(0.100)$ & $(0.205)$ & $(0.125)$ & $(0.156)$ \\
\hline \multirow[t]{2}{*}{ reer1 } & $-0.139 * * *$ & $-0.195^{* * *}$ & $-0.051^{* * *}$ & -0.034 & $-0.144^{* * *}$ & $-0.110^{* *}$ \\
\hline & $(0.024)$ & $(0.024)$ & $(0.019)$ & $(0.054)$ & $(0.044)$ & $(0.050)$ \\
\hline \multirow[t]{2}{*}{ wcoor } & $8.452^{* * *}$ & $5.082^{* *}$ & $5.571^{* * *}$ & & & \\
\hline & $(2.594)$ & $(2.463)$ & $(2.038)$ & & & \\
\hline \multirow[t]{2}{*}{ ucyclewcoor } & $0.175^{* *}$ & $0.147^{* *}$ & -0.058 & & & \\
\hline & $(0.088)$ & $(0.062)$ & $(0.068)$ & & & \\
\hline \multirow{2}{*}{ reer1wcoor } & $-0.084 * * *$ & $-0.048^{* *}$ & $0.057^{* * *}$ & & & \\
\hline & $(0.026)$ & $(0.024)$ & $(0.020)$ & & & \\
\hline \multirow[t]{2}{*}{ ud } & & & & $0.432^{* * *}$ & 0.178 & -0.254 \\
\hline & & & & $(0.157)$ & $(0.139)$ & $(0.155)$ \\
\hline \multirow[t]{2}{*}{ ucycleud } & & & & 0.009 & $0.008^{* *}$ & -0.001 \\
\hline & & & & $(0.006)$ & $(0.004)$ & $(0.005)$ \\
\hline \multirow[t]{2}{*}{ reer1ud } & & & & $-0.004^{* * *}$ & $-0.002^{*}$ & $0.003^{*}$ \\
\hline & & & & $(0.002)$ & $(0.001)$ & $(0.002)$ \\
\hline \multirow[t]{2}{*}{ bgro } & $6.844^{* * *}$ & $7.836^{* * *}$ & 0.191 & $6.422^{* * *}$ & $8.037^{* * *}$ & $1.615^{* *}$ \\
\hline & (1.057) & (1.452) & (0.758) & $(1.287)$ & $(1.545)$ & $(0.789)$ \\
\hline \multirow[t]{2}{*}{ baltic } & $3.419 * * *$ & $3.962^{* * *}$ & 0.269 & $3.816^{* * *}$ & $4.214^{* * *}$ & 0.399 \\
\hline & (0.819) & $(0.613)$ & $(0.668)$ & $(0.952)$ & $(0.652)$ & $(0.663)$ \\
\hline \multirow[t]{2}{*}{ ceec } & $1.492^{* * *}$ & $2.580^{* * *}$ & $0.994^{*}$ & $1.329^{* *}$ & $2.581^{* * *}$ & $1.252^{* * *}$ \\
\hline & $(0.538)$ & $(0.378)$ & $(0.516)$ & $(0.534)$ & $(0.365)$ & $(0.480)$ \\
\hline \multirow[t]{2}{*}{ periph } & $1.374^{* * *}$ & $0.731^{*}$ & -0.722 & $1.037^{* *}$ & 0.623 & -0.414 \\
\hline & $(0.435)$ & $(0.409)$ & $(0.541)$ & $(0.435)$ & $(0.430)$ & $(0.510)$ \\
\hline \multirow[t]{2}{*}{ Constant } & $14.415^{* * *}$ & $23.071^{* * *}$ & $8.410^{* * *}$ & 4.472 & $17.335^{* * *}$ & $12.863^{* *}$ \\
\hline & $(2.470)$ & $(2.871)$ & $(1.975)$ & $(5.452)$ & $(4.513)$ & (5.071) \\
\hline Year FE & YES & YES & YES & YES & YES & YES \\
\hline Observations & 396 & 396 & 396 & 369 & 369 & 369 \\
\hline R-squared & 0.746 & 0.823 & 0.226 & 0.472 & 0.670 & 0.210 \\
\hline $\begin{array}{l}\text { Unit root test } \\
\text { (p-value) }\end{array}$ & $\begin{array}{c}-6.992 \\
(0.000)\end{array}$ & $\begin{array}{c}-5.668 \\
(0.000)\end{array}$ & $\begin{array}{l}-7.870 \\
(0.000)\end{array}$ & $\begin{array}{l}-8.116 \\
(0.000)\end{array}$ & $\begin{array}{l}-1.609 \\
(0.054)\end{array}$ & $\begin{array}{c}-8.946 \\
(0.000)\end{array}$ \\
\hline $\begin{array}{l}\text { Test for no serial } \\
\text { Correlation } \\
\text { (p-value) }\end{array}$ & $\begin{array}{c}1.386 \\
(0.250)\end{array}$ & $\begin{array}{l}20.553 \\
(0.001)\end{array}$ & $\begin{array}{c}0.317 \\
(0.578)\end{array}$ & $\begin{array}{c}0.093 \\
(0.763) \\
\end{array}$ & $\begin{array}{l}10.313 \\
(0.004)\end{array}$ & $\begin{array}{c}0.064 \\
(0.803) \\
\end{array}$ \\
\hline
\end{tabular}

Robust standard errors in parenthesis. ${ }^{* * *} \mathrm{p}<0.01,{ }^{* *} \mathrm{p}<0.05,{ }^{*} \mathrm{p}<0.1$ 
Table 6. Robustness checks: sample size and variables definitions

\begin{tabular}{|c|c|c|c|c|c|c|c|c|c|c|c|c|}
\hline & \multicolumn{4}{|c|}{ Pre-2009 sample } & \multicolumn{4}{|c|}{ Model-based measure of unemployment gap } & \multicolumn{4}{|c|}{ Luxembourg excluded } \\
\hline \multirow[b]{2}{*}{ VARIABLES } & (1) & $(2)$ & (3) & $(4)$ & (5) & $(6)$ & (7) & $(8)$ & (9) & $(10)$ & $(11)$ & $(12)$ \\
\hline & Traded & Non-Traded & Traded & Non-Traded & Traded & Non-Traded & Traded & Non-Traded & Traded & Non-Traded & Traded & Non-Traded \\
\hline \multirow[t]{2}{*}{ u_cycle } & $-0.446^{* * *}$ & $-0.658^{* * *}$ & $-0.573^{* *}$ & $-0.849 * * *$ & $-0.261^{* *}$ & $-0.453^{* * *}$ & $-0.294^{* *}$ & $-0.587^{* * *}$ & $-0.327^{* *}$ & $-0.539 * * *$ & $-0.509 * *$ & $-0.859^{* * *}$ \\
\hline & $(0.140)$ & $(0.119)$ & $(0.222)$ & $(0.156)$ & (0.109) & $(0.068)$ & $(0.143)$ & $(0.085)$ & $(0.127)$ & $(0.120)$ & $(0.206)$ & $(0.146)$ \\
\hline \multirow[t]{2}{*}{ reer1 } & $-0.169 * * *$ & $-0.205^{* * *}$ & -0.017 & $-0.205^{* * *}$ & $-0.152^{* * *}$ & $-0.178^{* * *}$ & -0.032 & $-0.123^{* * *}$ & $-0.134^{* * *}$ & $-0.226^{* * *}$ & -0.026 & -0.070 \\
\hline & $(0.032)$ & $(0.030)$ & $(0.069)$ & $(0.058)$ & $(0.027)$ & $(0.026)$ & $(0.053)$ & $(0.039)$ & $(0.024)$ & $(0.029)$ & $(0.053)$ & $(0.071)$ \\
\hline \multirow[t]{2}{*}{ wcoor } & $7.159 * *$ & $4.890^{*}$ & & & $6.769^{* *}$ & 3.012 & & & $8.918^{* * *}$ & $5.517^{* *}$ & & \\
\hline & $(2.834)$ & $(2.792)$ & & & (2.819) & $(2.061)$ & & & $(2.592)$ & $(2.523)$ & & \\
\hline \multirow[t]{2}{*}{ ucyclewcoo } & $0.267^{* *}$ & $0.146^{* *}$ & & & $0.142^{* *}$ & $0.110^{* * *}$ & & & $0.171^{*}$ & $0.143^{* *}$ & & \\
\hline & $(0.105)$ & $(0.071)$ & & & $(0.066)$ & $(0.038)$ & & & $(0.089)$ & $(0.063)$ & & \\
\hline \multirow[t]{2}{*}{ reer1wcoor } & $-0.070^{* *}$ & $-0.046^{*}$ & & & $-0.067^{* *}$ & -0.029 & & & $-0.088^{* * *}$ & $-0.053^{* *}$ & & \\
\hline & $(0.028)$ & $(0.027)$ & & & $(0.028)$ & $(0.020)$ & & & $(0.026)$ & $(0.025)$ & & \\
\hline \multirow[t]{2}{*}{ ud } & & & $0.515^{* * *}$ & 0.078 & & & $0.425^{* * *}$ & 0.214 & & & $0.444^{* * *}$ & 0.488* \\
\hline & & & $(0.169)$ & $(0.147)$ & & & $(0.155)$ & $(0.136)$ & & & $(0.158)$ & $(0.278)$ \\
\hline \multirow[t]{2}{*}{ ucycleud } & & & 0.010 & $0.009 * *$ & & & 0.005 & $0.007^{* * *}$ & & & 0.009 & $0.012^{* *}$ \\
\hline & & & $(0.006)$ & $(0.004)$ & & & $(0.004)$ & $(0.002)$ & & & $(0.006)$ & $(0.005)$ \\
\hline \multirow[t]{2}{*}{ reer1ud } & & & $-0.005^{* * *}$ & -0.001 & & & $-0.004^{* * *}$ & -0.002 & & & $-0.004^{* * *}$ & $-0.005^{*}$ \\
\hline & & & $(0.002)$ & $(0.001)$ & & & $(0.002)$ & $(0.001)$ & & & $(0.002)$ & $(0.003)$ \\
\hline \multirow[t]{2}{*}{ bgro } & $6.509 * * *$ & $8.954^{* * *}$ & $6.421^{* * *}$ & $7.868^{* * *}$ & $6.506^{* * *}$ & $8.121^{* * *}$ & $6.453^{* * *}$ & $8.129^{* * *}$ & $7.105^{* * *}$ & $10.599^{* * *}$ & $6.591^{* * *}$ & $8.908^{* * *}$ \\
\hline & $(1.345)$ & $(1.737)$ & $(1.390)$ & (1.594) & $(1.248)$ & (1.582) & (1.290) & $(1.572)$ & $(1.061)$ & (1.933) & $(1.295)$ & $(1.634)$ \\
\hline \multirow[t]{2}{*}{ baltic } & $3.098^{* * *}$ & $3.964^{* * *}$ & $4.090^{* * *}$ & $4.108^{* * *}$ & $4.128^{* * *}$ & $4.535^{* * *}$ & $4.051^{* * *}$ & $4.681^{* * *}$ & $3.662^{* * *}$ & $3.812^{* * *}$ & $3.957^{* * *}$ & $4.189 * * *$ \\
\hline & (0.859) & $(0.717)$ & $(0.986)$ & $(0.735)$ & $(0.966)$ & $(0.702)$ & $(0.973)$ & $(0.693)$ & $(0.813)$ & $(0.646)$ & $(0.952)$ & $(0.655)$ \\
\hline \multirow[t]{2}{*}{ ceec } & $1.361^{* *}$ & $2.590 * * *$ & $1.232^{*}$ & $2.392^{* * *}$ & $1.547^{* * *}$ & $2.673^{* * *}$ & $1.376^{* *}$ & $2.714^{* * *}$ & $1.729 * * *$ & $2.409^{* * *}$ & $1.483^{* * *}$ & $2.358^{* * *}$ \\
\hline & $(0.646)$ & $(0.460)$ & $(0.650)$ & $(0.483)$ & $(0.537)$ & $(0.378)$ & $(0.535)$ & $(0.365)$ & $(0.526)$ & $(0.420)$ & $(0.527)$ & $(0.426)$ \\
\hline \multirow[t]{2}{*}{ periph } & $1.473^{* * *}$ & 0.772 & $1.068^{* *}$ & 0.446 & $1.315^{* * *}$ & $0.938^{* *}$ & $1.133^{* *}$ & 0.832* & $1.582^{* * *}$ & $0.717^{*}$ & $1.174^{* * *}$ & 0.472 \\
\hline & $(0.530)$ & $(0.529)$ & $(0.511)$ & $(0.518)$ & $(0.434)$ & $(0.394)$ & $(0.439)$ & $(0.427)$ & $(0.432)$ & $(0.405)$ & $(0.439)$ & $(0.476)$ \\
\hline \multirow[t]{2}{*}{ Constant } & $17.08^{* * *}$ & $23.90^{* * *}$ & 2.708 & $23.34^{* * *}$ & $16.67^{* * *}$ & $21.52^{* * *}$ & 4.282 & $15.22^{* * *}$ & $13.85^{* * *}$ & $27.24^{* * *}$ & 3.76 & $11.17^{*}$ \\
\hline & $(3.132)$ & (3.459) & $(6.944)$ & (6.088) & $(2.616)$ & $(3.236)$ & (5.365) & $(3.965)$ & $(2.471)$ & $(3.680)$ & $(5.436)$ & (6.607) \\
\hline Year FE & YES & YES & YES & YES & YES & YES & YES & YES & YES & YES & YES & YES \\
\hline Obs. & 320 & 320 & 304 & 304 & 368 & 368 & 368 & 368 & 380 & 380 & 353 & 353 \\
\hline R-squared & 0.785 & 0.837 & 0.513 & 0.675 & 0.475 & 0.661 & 0.464 & 0.662 & 0.758 & 0.727 & 0.494 & 0.613 \\
\hline
\end{tabular}

Note: See text for explanation of the specifications changes introduced in this table. Robust standard errors in parentheses. ${ }^{* * *} \mathrm{p}<0.01,{ }^{* *} \mathrm{p}<0.05,{ }^{*} \mathrm{p}<0.1$. 
Table 7. Robustness Checks: Treating autocorrelation

\begin{tabular}{|c|c|c|c|c|c|c|}
\hline & \multicolumn{2}{|c|}{ AR(1) disturbances } & \multicolumn{4}{|c|}{ Lagged cross-sector inflation } \\
\hline VARIABLES & $\begin{array}{c}(1) \\
\text { Non- } \\
\text { Traded }\end{array}$ & $\begin{array}{c}\text { (2) } \\
\text { Non-Traded }\end{array}$ & $\begin{array}{c}(3) \\
\text { Traded }\end{array}$ & $\begin{array}{c}\text { (4) } \\
\text { Non-Traded }\end{array}$ & $\begin{array}{c}(5) \\
\text { Traded }\end{array}$ & $\begin{array}{c}\text { (6) } \\
\text { Non-Traded }\end{array}$ \\
\hline u_cycle & $\begin{array}{c}-0.631^{* * *} \\
(0.093)\end{array}$ & $\begin{array}{c}-0.901^{* * *} \\
(0.152)\end{array}$ & $\begin{array}{l}-0.227^{*} \\
(0.129)\end{array}$ & $\begin{array}{c}-0.531^{* * *} \\
(0.082)\end{array}$ & $\begin{array}{c}-0.421^{* *} \\
(0.211)\end{array}$ & $\begin{array}{c}-0.604^{* * *} \\
(0.114)\end{array}$ \\
\hline reer1 & $\begin{array}{c}-0.228^{* * *} \\
(0.022)\end{array}$ & $\begin{array}{c}-0.110^{* *} \\
(0.051)\end{array}$ & $\begin{array}{c}-0.067^{* *} \\
(0.026)\end{array}$ & $\begin{array}{c}-0.104^{* * *} \\
(0.019)\end{array}$ & $\begin{array}{c}0.013 \\
(0.056)\end{array}$ & $\begin{array}{l}-0.078^{*} \\
(0.041)\end{array}$ \\
\hline infl_t1 & & & & $\begin{array}{c}0.231^{* * *} \\
(0.057)\end{array}$ & & $\begin{array}{c}0.327^{* * *} \\
(0.086)\end{array}$ \\
\hline infl_n1 & & & $\begin{array}{l}0.163^{* *} \\
(0.075)\end{array}$ & & $\begin{array}{c}-0.060 \\
(0.199)\end{array}$ & \\
\hline wcoord & $\begin{array}{c}1.562 \\
(2.035)\end{array}$ & & $\begin{array}{c}9.552^{* * *} \\
(2.510)\end{array}$ & $\begin{array}{c}2.355 \\
(1.678)\end{array}$ & & \\
\hline ucyclewcoord & $\begin{array}{l}0.147^{* *} \\
(0.069)\end{array}$ & & $\begin{array}{c}0.221^{* * *} \\
(0.082)\end{array}$ & $\begin{array}{l}0.130^{* *} \\
(0.053)\end{array}$ & & \\
\hline reer1wcoord & $\begin{array}{l}-0.012 \\
(0.020)\end{array}$ & & $\begin{array}{c}-0.098^{* * *} \\
(0.024)\end{array}$ & $\begin{array}{l}-0.023 \\
(0.016)\end{array}$ & & \\
\hline inft1wcoord & & & & $\begin{array}{c}0.063 \\
(0.047)\end{array}$ & & \\
\hline infn1wcoord & & & $\begin{array}{c}0.069^{*} \\
(0.038)\end{array}$ & & & \\
\hline ud & & $\begin{array}{l}0.348^{* *} \\
(0.162)\end{array}$ & & & $\begin{array}{l}0.312^{* *} \\
(0.154)\end{array}$ & $\begin{array}{c}0.058 \\
(0.117)\end{array}$ \\
\hline ucycleud & & $\begin{array}{c}0.015^{* * *} \\
(0.005)\end{array}$ & & & $\begin{array}{c}0.009^{*} \\
(0.006)\end{array}$ & $\begin{array}{l}0.006^{*} \\
(0.004)\end{array}$ \\
\hline reer1ud & & $\begin{array}{l}-0.003^{*} \\
(0.002)\end{array}$ & & & $\begin{array}{c}-0.003^{* *} \\
(0.001)\end{array}$ & $\begin{array}{l}-0.000 \\
(0.001)\end{array}$ \\
\hline inft1ud & & & & & & $\begin{array}{l}-0.001 \\
(0.002)\end{array}$ \\
\hline infn1ud & & & & & $\begin{array}{l}0.011^{* *} \\
(0.005)\end{array}$ & \\
\hline bgro & $\begin{array}{c}9.040^{* * *} \\
(1.143)\end{array}$ & $\begin{array}{c}8.974^{* * *} \\
(1.078)\end{array}$ & $\begin{array}{c}4.791^{* * *} \\
(1.042)\end{array}$ & $\begin{array}{c}4.268^{* * *} \\
(0.892)\end{array}$ & $\begin{array}{c}3.315^{* * *} \\
(1.067)\end{array}$ & $\begin{array}{c}4.625^{* * *} \\
(0.875)\end{array}$ \\
\hline baltic & $\begin{array}{c}4.750^{* * *} \\
(0.995)\end{array}$ & $\begin{array}{c}4.733^{* * *} \\
(0.934)\end{array}$ & $\begin{array}{c}2.099 * * * \\
(0.797)\end{array}$ & $\begin{array}{c}2.401^{* * *} \\
(0.552)\end{array}$ & $\begin{array}{c}2.734^{* * *} \\
(0.923)\end{array}$ & $\begin{array}{c}2.701^{* * *} \\
(0.533)\end{array}$ \\
\hline ceec & $\begin{array}{c}2.652^{* * *} \\
(0.788)\end{array}$ & $\begin{array}{c}2.639^{* * *} \\
(0.693)\end{array}$ & $\begin{array}{c}0.737 \\
(0.589)\end{array}$ & $\begin{array}{c}1.959^{* * *} \\
(0.348)\end{array}$ & $\begin{array}{c}0.354 \\
(0.651)\end{array}$ & $\begin{array}{c}2.055^{* * *} \\
(0.342)\end{array}$ \\
\hline periph & $\begin{array}{c}0.687 \\
(0.833)\end{array}$ & $\begin{array}{c}0.660 \\
(0.727)\end{array}$ & $\begin{array}{c}1.265^{* * *} \\
(0.446)\end{array}$ & $\begin{array}{c}0.239 \\
(0.384)\end{array}$ & $\begin{array}{c}0.893^{*} \\
(0.461)\end{array}$ & $\begin{array}{c}0.213 \\
(0.403)\end{array}$ \\
\hline Constant & $\begin{array}{c}25.060^{* * *} \\
(2.307)\end{array}$ & $\begin{array}{c}12.253^{* *} \\
(5.186)\end{array}$ & $\begin{array}{l}6.806^{* *} \\
(2.926)\end{array}$ & $\begin{array}{c}13.049^{* * *} \\
(2.009)\end{array}$ & $\begin{array}{c}0.357 \\
(5.981)\end{array}$ & $\begin{array}{l}9.875^{* *} \\
(4.181)\end{array}$ \\
\hline Year FE & YES & YES & YES & YES & YES & YES \\
\hline Observations & 396 & 369 & 370 & 370 & 346 & 346 \\
\hline R-squared & 0.718 & 0.493 & 0.620 & 0.781 & 0.496 & 0.736 \\
\hline $\begin{array}{l}\text { Rho } 1 \\
\text { Test for no seri } \\
\text { (p.value) }\end{array}$ & $\begin{array}{l}0.507 \\
\text { orrel. }\end{array}$ & 0,415 & $\begin{array}{c}0.027 \\
(0.871)\end{array}$ & $\begin{array}{c}12.88 \\
(0.002)\end{array}$ & $\begin{array}{c}0.027 \\
(0.872)\end{array}$ & $\begin{array}{c}6.377 \\
(0.018)\end{array}$ \\
\hline
\end{tabular}

Robust standard errors in parentheses. ${ }^{* * *} \mathrm{p}<0.01,{ }^{* *} \mathrm{p}<0.05,{ }^{*} \mathrm{p}<0.1$. Rho 1 is the GLS-estimated AR(1) coefficient. 